\title{
Studying the effect of mineral nutrition on the antifungal activity of a strain of Bacillus subtilis, the producer of an experimental sample of a biological product \\ Gyrnets A.A., Asaturova A.M., Allakhverdyan V.V.
}

Federal State-Funded Scientific Institution «All-Russian Research Institute of Biological Plant Protection», Krasnodar, Russia E-mail: evgenijgyrnets@mail.ru

Key message. The research shows a raise of mineral components bioavailability and increase of antifungal activity of strainproducer Bacillus subtilis BZR $336 \mathrm{~g}$ by addition of citric acid in a nutrient medium.

Keywords: citric acid, mineral nutrition, antifungal activity, Bacillus subtilis

One of the main problems of the biotechnology of microorganisms is a bioavailability of components of nutrient mediums. The composition of industrial environments includes mineral components, some of which remain in undissolved form, that significantly reduces their digestibility. It is well known that a citric acid forms chelate complexes with metal ions move up into the soluble form (Verhoff, Bauweleers, 2014). In this connection, the aim of our research is to select the necessary concentration of a citric acid and determine its influence on the antifungal activity of the strain Bacillus subtilis BZR 336g.

The strain B. subtilis BZR 336g, having fungicidal activity, was grown under conditions of periodic cultivation on a nutrient medium with the addition of a gradient of citric acid concentrations. The antifungal activity of metabolites of the culture fluid was studied by method of bioautography. (Sidorova, Asaturova, Homyak, 2019). The antifungal activity of the strain and components of the nutrient medium was studied by method of double cultures. Calculation was carried out on the 5th, 10th, 15 th and 20th days. (Netrusov, 2004). In both cases the test-object was Fusarium oxysporum var. orthoceras Appel \& Wollenw. The sizes of the zones of inhibition of the test culture were estimated, and in the method of bioautography is also their number. The manifestation of the fungistatic effect was also taken into the calculation.

It was found that from 10 accounting days of double cultures, the antifungal activity of the strain grown on a nutrient medium with the addition of a citric acid, in comparison with the original composition, increased 1.5 times and remained at that level for 20 days. The bioautographic analysis showed that in the culture liquid, selected from medium with a citric acid, the synthesis of iturin with a fungicidal effect and surfactin which according to our data has a significant fungistatic effect are significantly higher. Based on this, the addition of a citric acid is significantly improved the mineral nutrition of the strain $B$. subtilis BZR 336g and raised its antifungal activity. It allows to recommend a citric acid as the substance in conditions of the periodical cultivation.

\section{Изучение влияния минерального питания на антифунгальную активность штамма Bacillus subtilis - продуцента экспериментального образца биопрепарата \\ Гьрнеи А.А., Асатурова А.М., Аллахвердян В.В.}

Федеральное государственное бюджетное научное учреждение «Всероссийский научно-исследовательский институт биологической защиты растений», Краснодар, Россия

\begin{abstract}
Аннотация. В исследовании показаны повышение биодоступности минеральных компонентов и увеличение антифунгальной активности итамма-продуцента биопрепарата Bacillus subtilis BZR $336 g$ nутем добавление
\end{abstract} лимонной кислоты в питательную среду.

Ключевые слова: лимонная кислота, минеральное питание, антифунгальная активность, Bacillus subtilis

Одной из главных проблем биотехнологии микроорганизмов является биодоступность компонентов питательных сред. В состав промышленных сред входят минеральные компоненты, часть которых остается в нерастворенной форме, что значительно снижает их усваиваемость. Известно, что лимонная кислота образует с ионами металлов хелатные комплексы, переводя их в растворимую форму (Verhoff, Bauweleers, 2014). В связи с этим, цель нашего исследования - подобрать необходимую концентрацию лимонной кислоты и определить ее влияние на антифунгальную активность штамма Bacillus subtilis BZR 336g.

Штамм B. subtilis BZR 336g, обладающий фунгицидной активностью, выращивали в условиях периодического культивирования на питательной среде с добавлением градиента концентраций лимонной кислоты. Антифунгальную активность метаболитов культуральной жидкости изучали методом биоавтографии (Сидорова, Асатурова, Хомяк, 2019). Антифунгальную активность штамма и компонентов питательной среды - методом двойных культур: учет проводили на 5е, 10-е, 15-е и 20-е сутки (Нетрусов, 2004). В обоих случаях тест-объектом был Fusarium oxysporum var. orthoceras Appel \& Wollenw. Оценивались размеры зон ингибирования тест-культуры, а в методе биоавтографии еще и их количество. Учитывалось также проявление фунгистатического эффекта.

Обнаружено, что с 10-х учетных суток двойных культур антифунгальная активность штамма, выращенного на питательной среде с добавлением лимонной кислоты, в сравнении оригинальным составом возрастала в 1,5 раза и сохранялась на таком уровне на протяжении 20 дней. Биоавтографический анализ показал, что в культуральной жидкости, отобранной из среды с лимонной кислотой, значительно выше синтез итурина, обладающиего фунгицидным действием, и сурфактина, который, по нашим данным, обладает значительным фунгистатическим эффектом. Из этого следует, что добавление лимонной кислоты значительно улучшило минеральное питание штамма B. subtilis BZR 336g и повысило его антифунгальную активность. Это позволяет рекомендовать лимонную кислоту в качестве субстрата в условиях периодического культивирования.

1. Verhoff F. H., Bauweleers H. Citric Acid / Ullmann's Encyclopedia of Industrial Chemistry - Wiley-VCH, 2014. - P. 5.

2. Сидорова Т.М., Асатурова А.М., Хомяк А.И. и др. Выделение и характеристика антигрибных метаболитов штаммов Bacillus subtilis BZR 336g и Bacillus subtilis BZR 517 модифицированным методом биоавтографии / Сельскохозяйственная биология. 2019. Т. 54. № 1, с. 178-185

3.Нетрусов А. И. Микробиология: учеб. пособие / А. И. Нетрусов, И. Б. Котова - М.: Академия, 2009. 352 с. 